\title{
Implementation of the ISPS Code at Marinas: The Greek Case.
}

\author{
Aggeliki Pardali ${ }^{1}$, George Spyridon ${ }^{2}$, Vasiliki Paraschou ${ }^{3 *}$ \\ ${ }^{1}$ Professor at University of Piraeus, Port Economics \\ ${ }^{2}$ Lieutenant HCG (Hellenic Coast Guard) \\ ${ }^{3}$ Phd candidate at University of Piraeus, Maritime studies Dpt
}

*Corresponding Author: Vasiliki Paraschou, Phd candidate at University of Piraeus, Maritime studies $D p t$

\begin{abstract}
Greece, a country with lacy shores and many, small, beautiful islands and rocky islets, is a magnificent place for yachting marine tourism.

Greek seas are considered safe as distances between the coasts are small, while conditions related to wind, temperature and atmosphere most months are favorable. Apart from the development of port infrastructure, the quality of the port product also plays a significant role in developing yachting marine tourism. In the port industry, the main elements of quality and therefore competitiveness are: reliability, time consistency as well as safety and security.

In this article, we will explore the possibility of applying the ISPS code at Greek marinas, so that they become attractive both to mega yachts and to improve their quality - Security and therefore their competitiveness with the ultimate aim of developing this sector in Greece.
\end{abstract}

Keywords: ISPS, Greek marinas, security

\section{INTRODUCTION}

According to the basic criterion of sea activities distinction, we end up to two main tourist activities, Cruise Activity and Private Sea Navigation (Yachting). By the term "Yachting" we mean a vessel chartering in order to be used both as a place of residence and entertainment and as a mean of transport by a group of people who have the ability to choose and form together their marine navigation program for their leisure purposes (Diakomichalis M., 2009).

Marine tourism sector consists of port infrastructure and marine resources. Marinas, ports, anchorages and shelters constitute port infrastructure, whereas vessels and sea voyages are considered to be marine resources. Consequently, yachting is directly linked to the chartering of various categories of yachts. The chartering results from the demand generated by the various consumers/users of this service, which includes pleasure trips to the sea, in different ports and coasts. The chartering process, which is mainly aimed at high-income customers, is considered to be the most productive and most foreign exchange activity of marine tourism (Igoumenakis N. 1998) and (Hall M., 2011).

The development of this form of tourism requires the existence of specific yacht ports infrastructure and investments possibility in each area that expects maritime tourism development. Port facilities that will ensure vessels mooring safety, as well as additional facilities that will provide vessels with food, fuel, electricity and other supplies are necessary. Finally, the equipment of these ports must be modern in order to fulfill the requirements of users/passengers at the highest level. In this context, port security systems are of paramount importance.

Currently, cruise industry tends to adopt horizontal and vertical integration, a fact that has led to a continuous gigantism of both companies and ships involved in this market. These ships require corresponding port terminals with the appropriate infrastructure and superstructure. In Greece there are ports which can provide these facilities (Piraeus, Katakolo, Heraklion, Rhodes, etc.). Smaller ports but very tourist like Mykonos, Santorini, etc. do not have the corresponding infrastructure, while the 
huge number of passengers disembarking on these small islands, especially at high season periods, creates a great deal of overcrowding, which downgrades the tourist product of the islands overall.

Greece, a country with lacy shores and many, small, beautiful islands and rocky islets, is a magnificent place for yachting marine tourism. Along with the long history of the region, infinite historical monuments of great historical value, numerous museums and archeological places, Greece sets the ideal scene for sea tourism to grow. Greek seas are considered safe as distances between the coasts are small, while conditions related to wind, temperature and atmosphere most months are favorable.

Taking into account the above mentioned data for Greece, the predominant model for developing sea tourism seems to be yachting, as it can be developed in smaller scales and not massive cruise tourism. The quality of the port product also plays an important role in developing marine tourism in addition to the development of port infrastructure. In the port industry, the main elements of quality and therefore competitiveness are: reliability, time consistency as well as safety and security.

In this article, we will explore the possibility of applying the ISPS code on Greek marinas, so that they become attractive both to mega yachts and to improve their quality - security and therefore their competitiveness with the ultimate aim of developing this sector in Greece.

\section{MARINAS IN GREECE}

\subsection{Ownership}

The first marinas in Greece started their construction in 1960, initiated by the Greek National Tourism Organization. Since 1993, there were twelve marinas with a capacity of 4570 berths, under almost exclusively public sector's operation (mainly G.N.T.O), distributed at the major urban centers, particularly in Attica. Till then, the institutional framework for marinas in Greece, not only excluded private sector from manufacturing marinas, but it also prohibited the exclusive use and exploitation of the seashore. Law No 2160/93 lifted this ban and allowed any interested part to construct marinas with the preposition of owning/holding property in front of the construction area, only by obtaining approval from the Interministerial Committee and the Secretariat for Support of Tourist Ports (Pardali A., Giantzi T. 2018).

The same law also granted G.N.T.O. the right to grant its marinas to a group of public or private interests (www.pcci.gr 2018). Hence marinas managing passed to local government, port funds, individuals and the State Property Company (Pardali, A., and M. Miliaraki. 2006). The fact is that a large number of marinas in Greece are still unused. The work of the recovery has been undertaken by the Hellenic Republic Asset Development Fund (HRADF).

Most marinas are public but managed by private corporations. Today 18 operating Marinas are managed by private companies, 4 by municipalities, 4 by Port Funds and 2 by HRADF., according to the Ministry of Tourism. Important data: about $63 \%$ of the Greek Marinas capacity is managed by three companies, (38\% by one company, $17 \%$ by a second company and $8 \%$ by a third one), which leads us to conclude that a market concentration under development, since $63 \%$ of capacity is owned by 3 companies (figure 1 ).

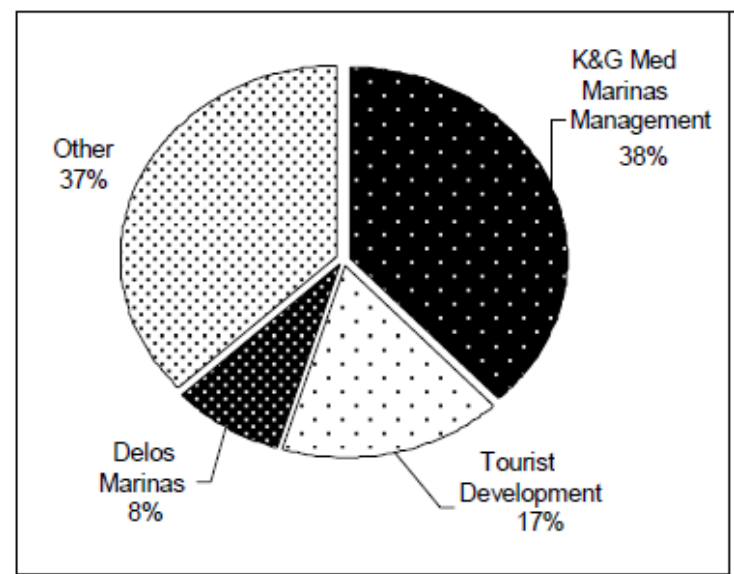

Figure1. Berths, by Management Company (in percentages).

Source: Pardali A. and Giantzi T., (2018) 


\subsection{Location of Greek Marinas}

Under current legislation, tourist ports are divided into the following categories: Marinas, Shelters and Anchorages. Hotel Ports was another category which was abolished by N.4070/2012 and now these ports fall into one of the above mentioned.

- «Marina» features land and sea facilities and high-standard infrastructure defined by decision of the Minister for Culture and Tourism, according to paragraph 3, Article 31 of Law No N.2160/1993, offering services to yachts and their users.

- «Shelter» has a basic building infrastructure of at least $300 \mathrm{sq} \mathrm{ft}$. providing the minimum of water, power, telephone, fuel, internet, residue and waste collection, fire-extinguishing, accommodation and health services.

- «Anchorage» is created within a protected bay, in lakes and rivers, with light equipment, which does not cause permanent deterioration of the environment with a limited number of berths and basic facilities

In Greece today, the surveyed marinas are 59 of which 35 are in operation, of which 28 are fully operational and 8 are under-operating. Of the marinas in service, 22 have established the "Greek Marinas Association". Of these, 8 marinas are located in the Attica region. Their total capacity is 8,497 berths. Dry docking berths were estimated at about 4,180, while 7 out of 22 marinas were Blue Flag awarded. Based on Ministry of Tourism data the marinas per region are presented in Figure 2.

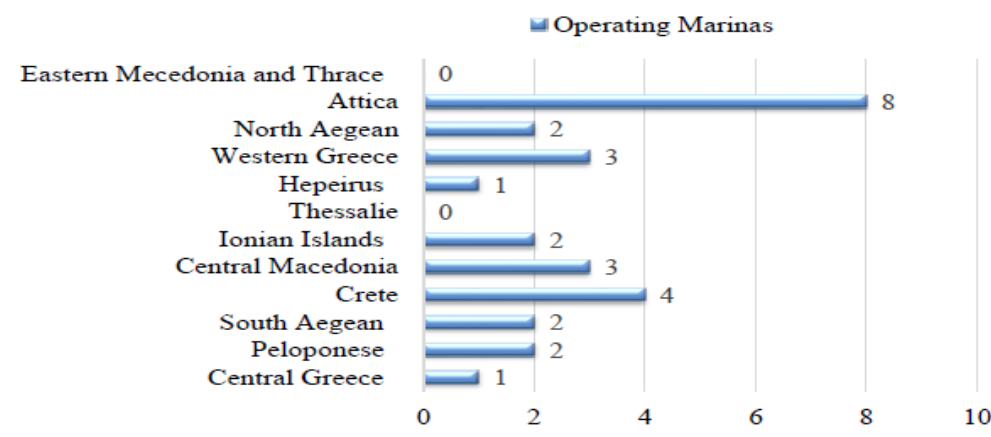

Figure2. Operating Marinas per Greek region

Source: Data from Ministry of Tourism (2017), personal analysis

\subsection{Greek Marinas' Capacity}

Greece currently has 8,497 berths and 8,200 boat mounting posts, according to data from the Ministry of Tourism and the Greek Marinas Association. It is obvious that Gouvia Marina holds the most berths, followed by the Alimos Marina, the Olympic Marina, the Marina Zeas, the Marina of Rhodes and the Marina of Lefkas (Figure 3). Most coastal passenger ports of the country also offer berths to the yachts; the number of berths stands approximately at 4,180 (Figure 4). Only 11 are for super yachts (Figure 5).

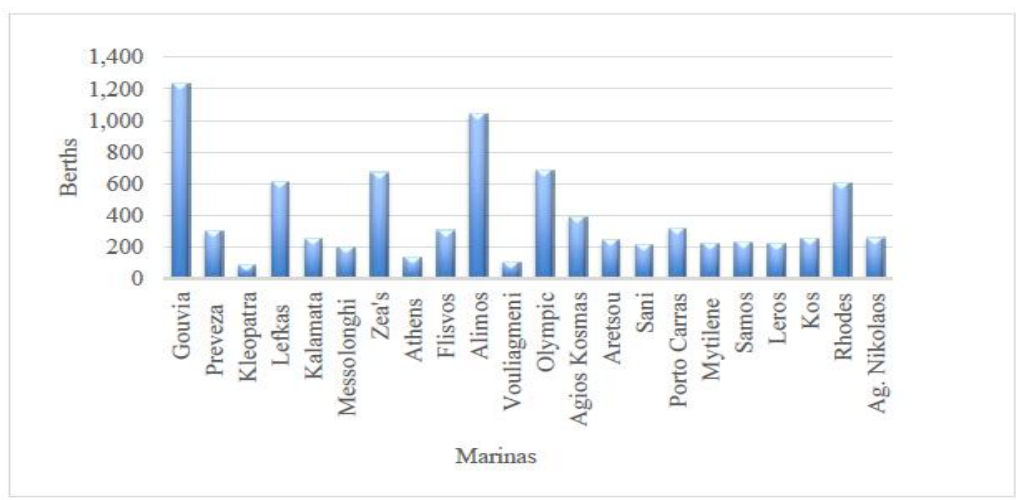

Figure3. Berths per Marina

Source: Greek Marinas Association, 2017 


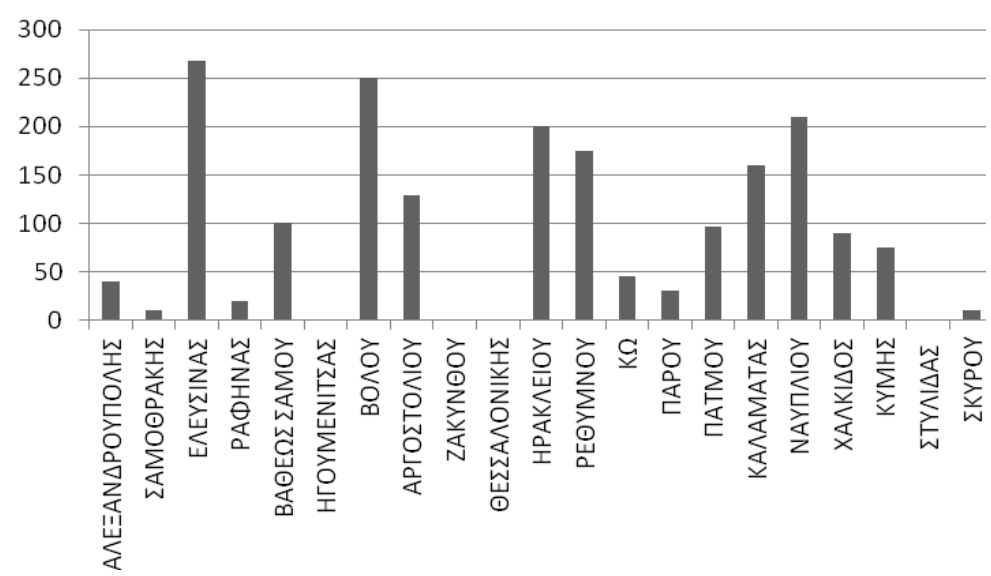

Figure4. Berths for yachts in commercial short sea ports, by region.

Source: Mantzios K., (2016), Database of Yacht Zones in existing ports, Diploma Thesis, Laboratory of Harbour Works, NTUA
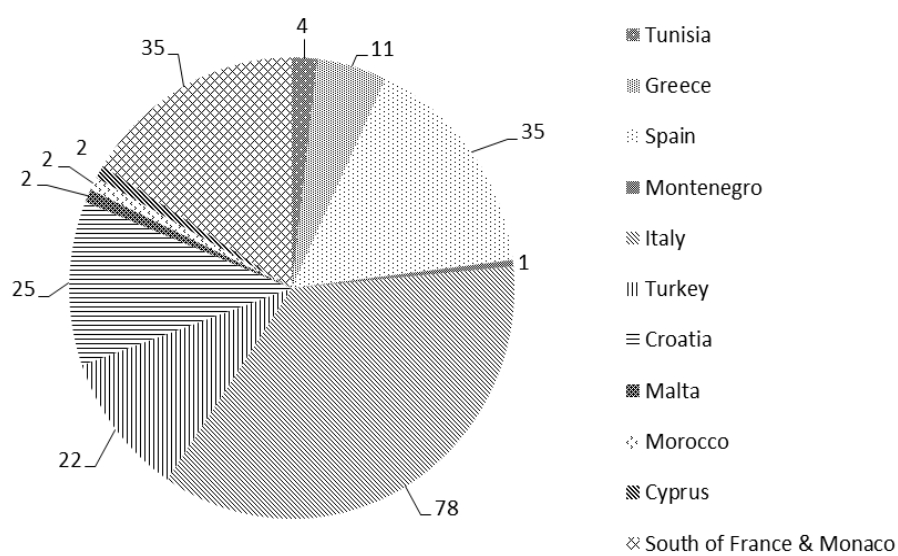

Figure5. Marinas for Super yachts in Mediterranean Sea

Source: The Super yacht, Summer 2017.

\section{Security as a Quality Element in Ports}

\subsection{Quality in Ports}

Many definitions have been given for quality. Quality is about value (Feigenbaum A. V.1993), ability to use (Juran JM, 1988), specifications (Gilmore j, 1994), compliance with requirements (Crosby PB, 1979), responsiveness to customer expectations and avoidance of losses (Ross MacKay, 1989). A commonly accepted definition by researchers defines quality as "a set of properties and characteristics of a service which support its ability to satisfy specific and predefined needs" (Kotler 1994).

The main elements of the concept of the quality of the port product are:

- The time and reliability in the production of the port product both overall and during the production process (e.g. loading and discharging speed, passengers' safe embarkation and disembarkation, cargo handling within the port terminal speed, speed in document handling, etc.) (Pardali 2007).

- Safety and security conditions in the production of the port product as a whole or in the production phase (damage, losses, etc.) (Pardali A, 2007).

However, concerning marinas we should point out that there are various programs for qualitative evaluation of modern marinas. The most important are the following:

- $\quad$ "5 Golden Anchors" from the Yacht Harbor Association (YHA)

International Journal of Research in Tourism and Hospitality (IJRTH) 
- Clean Marina, Clean Marina, of the International Council of Marine Industry Association (ICOMIA).

- «Blue Flag» program.

- ISO 9001/2015 Quality Management Certification and Environment ISO 14001/2004 programs.

- ISPS code

\subsection{Definition of Security}

A crucial factor that contributes to quality improvement and consequently increase the competitiveness of a port is 'safety \& security'. "Safety" refers to a safe and healthy environment for the employees and regards environmental protection issues. On the other hand, 'security' means avoiding illegal activities in the port area, whether they concern facilities, people or ships that are in breach of the rules. ${ }^{1}$

According to security rules, a security assessment shall be carried out at each port in order to analyze the potential threats, vulnerabilities, assessing the material assets of the facility and its operation in general. The security assessment of a port is considered to be a very important process and on this basis a port security plan setting out certain security measures relating to the preparation, prevention and process of addressing threats that endanger the security of the port, the people and the bodies involved in it, is being elaborated.(SOLASXI-2, ISPS Code)

\section{PORT SECURITY AND ISPS CODE}

\subsection{The ISPS Code for Ports}

\subsubsection{Objectives}

The main objectives of the ISPS Code are to establish an international framework which, through cooperation between States Parties, State Agencies, Local Administrations and the maritime and port industries, will be able to identify those factors which pose a security threat, while taking measures to prevent incidents which may put in danger the security of ships and port facilities used in international trade. (www.cimsec.org 2018)

Alongside, the Code aims to ensure maritime security by defining the roles and responsibilities of the above mentioned parties, while at the same time trying to ensure, in a valid and effective manner, the collection and exchange of security-related information. In addition, it sets out to provide a methodology for performing security assessments in order to allow for the implementation of adaptation plans and procedures at changing levels of security. Finally, the Code seeks aims to convince that adequate and appropriate maritime security measures are taken ${ }^{2}$.

\subsubsection{Requirements}

In order to achieve these objectives, the Code provides for certain operational requirements. These requirements include: entry prohibition of unauthorized explosive weapons or incendiary devices within port facilities or ships, prevent unauthorized access to ships, port facilities and restricted access zones, alert trigger in case of a security risk, ship security plans establishment and port facilities following an assessment thereof, and conduct appropriate training for familiarization with these plans. Finally, the requirements include the collection and evaluation of information relating to issues that pose a risk to safety ${ }^{3}$.

\footnotetext{
${ }^{1}$ ILO (2005), Safety and health in ports. ILO code of practice, International Labor Office, Geneva. ILO-IMO (2004), Security in ports. ILO and IMO code of practice, International Labor Office, Geneva/International Maritime Organization, London.

IMO (2017a). Report of the Maritime Safety Committee on its ninety-eighth session. MSC 98/23. London.

IMO document SOLAS/CONF.5/34 ANNEX I, 12, December 2002. p. 4.

IMO International Convention on the Safety for the safety of life at sea 1974 as amended (SOLAS Convention) (2011), Chapter XI-2, IMO, London.

2 European Regulation 725/04 paragraph 1.2 «For safety improvement in vessels and port facilities», www.europa.eu, Committee of European Communities official website

${ }^{3}$ European Regulation 725/04 paragraph 1.2 «For safety improvement in vessels and port facilities», www.europa.eu, Committee of European Communities official website
} 


\subsubsection{Field of Implementation}

The provisions of international and Community legislation shall apply (Hellberg P., 2009):

(a) In the following types of ships engaged in international voyages:

- Passenger ships, including high-speed passenger craft,

- Cargo ships, including high-speed craft, of 500 gross tonnage or more,

- Mobile offshore drilling units (IMO World Maritime Day 2005).

(b) Ship companies referred to in (a) as defined in Regulation IX/1 of the SOLAS Convention.

(c) passenger ships serving national traffic and falling within category (a) within the meaning of Article 4 of Council Directive 98/18/EC of 17 March 1998 on safety rules and standards for passenger ships and their companies as defined in Regulation IX/1 of the SOLAS Convention. ${ }^{4}$

(d) Port facilities in the territory serving ships in (a) and (c).

(e) Port facilities in the territory which, although primarily used by vessels not engaged on international voyages, are occasionally required to serve ships arriving or departing under international voyage. By decision of the Minister for Merchant Shipping, the Aegean and Island Policies the criteria and procedures are established for the designation and designation of a port facility as occasional international voyage ships and the extent to which Chapter XI2 of the SOLAS 74 International Convention and the Code applies to it.

f) In the ports of the territory where one or more port facilities referred to in (d) and (e) are located, with the exception of military port facilities.

(g) In areas related to the ports referred to in (f) as defined in the security assessment study in Article 7.

\subsubsection{Port Facilities Requirements}

Port facilities serving ships engaged on international voyages shall apply the provisions of the ISPS Code. The provisions of Part A of the Code shall apply only to the port facility designated as 'the area designated by the Contracting State or the competent authority, in which the ship/port interconnection takes place'. 'Ship/port interconnection' means interactions carried out directly or indirectly on a ship, such as the boarding/disembarkation of persons or loading/unloading of goods or the provision of port services to or from the ship, Such areas are anchorages, waiting positions and approach zones from the sea as appropriate.

The main obligations of the managing and operating body of a port facility are the following:

- Recruitment and training of the installer's security officer and other security personnel.

- Measures for the security and health of employees.

- the delegation and preparation of a port facility security assessment by the Contracting State or a recognized security organization

- the entrustment and development of the port facility security plan by a recognized security organization.

- ensuring the operation of the port facility in accordance with the security levels set by the Contracting State.

- ensuring the cooperation of the port facility manager with the services and persons involved.

\section{COST OF APPLYing ISPS TO PASSENGER PORTS AND MARINAS}

It's a fact that security in a port (marina) increases cost to both users and the operator. However, in order to implement the ISPS code, some expenditure is required, such as expenditure on (Protonotarios N., 2003):

- Port Facility Security Assessment Study

\footnotetext{
${ }^{4}$ SOLAS, Chapter XI-2 and Regulation (EU) 725/2004 «For safety improvement in vessels and port facilities», www.europa.eu, Committee of European Communities official website
} 
- Port Facility Security Plan

- Equipment (fencing, lighting, cameras, gate, etc.)

- Port facilities security officer's salaries

- Port facilities security officers training

- Port facility custody staff

- Guard staff training

- Annual exercise and every three months exercises

- Evaluation every five years.

\subsection{Introduction of a Reciprocal Charge for Funding The Implementation of Security Measures of The ISPS Code}

It is a fact that security as a quality element in ports creates costs for the company and a need for new investment, so the question arises as to who will bear this cost? First of all, the answer is obvious, the costs must be borne by the port operator. According to the economic practices, the port operator can embody these costs into the prices of the port services provided. This will result in a shift of the supply curve to the left, so some of this cost will be paid by users, part will be paid by the port company. The size of the costs borne by each operator depends on the elasticity of the demand for the port product. Flexibility depends on the existence of substitutes, i.e. the existence of competitors on the market. So these costs if they don't concern all the players in a market, they can distort competition.

In the light of the above facts and with a view to assisting operators in the management and operation of the coastal ports (Municipal \& Port Funds) to comply with security requirements, Greece has introduced a specific contributory fee in its legislation (Table 1$)^{5}$. This fee shall cover:

- Passenger ships, which are all defined as a ship carrying more than 12 passengers (in this case also include ships calling at the marinas); and

- Cargo ships where any non-passenger ship is designated.

Table1. Contributory ISPS fee for Coastal Ports

\begin{tabular}{|c|c|c|}
\hline DESCRIPTION & $\begin{array}{l}\text { MEASUREMENT } \\
\text { UNIT }\end{array}$ & $\begin{array}{l}\text { CONTRIBUTORY } \\
\text { FEE (euro) }\end{array}$ \\
\hline $\begin{array}{l}\text { Passenger ships serving national traffic falling within } \\
\text { category A within the meaning of Article } 4 \text { of Council } \\
\text { Directive } 98 / 18 / \mathrm{EC} \text { of } 17 \text { March } 1998 \text { and passenger } \\
\text { ships falling within the scope of Regulation No } \\
725 / 2004 \mathrm{EC} \text { and/or the ISPS Code and operate } \\
\text { international voyages. }\end{array}$ & $\begin{array}{l}\text { Per passenger } \\
\text { embarked from their } \\
\text { port facility. }\end{array}$ & $0,50 €$ \\
\hline $\begin{array}{l}\text { Passenger ships which fall within the scope of } \\
\text { Regulation 725/2004EC and/or the ISPS Code and } \\
\text { operate international navigation voyages. }\end{array}$ & Per passenger & $1 €$ \\
\hline
\end{tabular}

Source: Joint ministerial decision. Nr. 3113.11/43730/2017.

\section{INVESTIGATING IMPLEMENTATION OF ISPS CODE AT GREEK MARINAS.}

\subsection{Method}

In order to investigate both the level of security in the Greek marinas and the implementation of ISPS, a questionnaire was developed which was distributed to the Marinas Operators. The investigation lasted three months, from 01/06/2018 to 31/08/2018. Twenty-eight (28) questionnaires were sent out. We have received replies from seventeen (17) Greek marinas representing $60 \%$ of the total of the

\footnotetext{
5 Joint ministerial decision. Nr. 3113.11/43730/2017 «Establishment of contributory fees for the provision of security enhancement services for ships, port facilities and ports»
} 
country's twenty-eight (28) in operation of tourist ports. Six (6) out of seventeen (17) marinas, accounting for about 35\%, are located on the Attica coast, and in particular on the southern Attica coast front.

The methodological tool we used is the semi-structured questionnaire, which consists of eighteen (18) closed questions and three (3) open-ended questions. The questionnaire structure comprises three distinct sections with the first section (Questions 1 to 4 inclusive) dealing with the demographic data of the marinas. The second section (questions 5 to 11 inclusive) deals with the security and implementation of the ISPS Code, while the third section (questions 12 to 17 inclusive) deals with the costs of applying this Code.

All questionnaire replies were processed in the Statistical Package for Social Sciences software (S.P.S.S. 21). The treatment of the replies includes a descriptive analysis of the questions in the sample (variables) and a cross tabulation.

\subsection{Analysis}

First, we examined the berth allocation of the marinas in the sample. We have established that the average capacity of the sample marinas is 462 positions with the standard deviation being 334 positions. The fact is that the Greek marinas are extremely heterogeneous about their capacity.

As regards the ownership of the sampled marinas, $29 \%$ were found to be public companies and $71 \%$ private companies. Security seems to be a concern to the marinas' administrations, since only $5.9 \%$, a marina reveals that there is no security on its premises.

Regarding security systems, we note that the Greek marinas use six main systems. The most popular guard measures are space fences and security patrols with approximately $76.5 \%$, followed by the use of private security companies (70.5\%), surveillance systems (camera) (59\%), registration of inbound and outbound persons and vehicles (53\%) and use of an entry card (35\%).

Concerning ISPS code, the majority of respondents $(78.8 \%)$ have a positive view of the Code as a security tool. About its implementtation, approximately $94 \%$ of the sample indicates that it is not obligatory, and only 5.9\% apply it. The main reasons for not applying the Code are: the nonobligation to apply (50\%), high implementation costs (25\%), and other reasons (25\%)

Despite the non-implementation of the Code to the majority of Greek marinas, the managers involved in the survey recognize that the implementation of the ISPS Code improves the image of the marina (94.1\%). For the marinas that applied the ISPS Code, $11.8 \%$ observed a decrease in thefts and $5.9 \%$ attracted larger vessels and increased traffic.

The last section of the questionnaire deals with the cost of applying ISPS. In particular, the sampled tourist ports operators were asked about the financial capacity to support implementation of the ISPS Code. $58.8 \%$ of the respondents said they could not financially support the adoption and implementation of this Code, and about $78.8 \%$ of respondents had no plan to cover the implementation costs.

Asked if they would change their pricing policy if the ISPS Code were to be applied in the first place, $52.9 \%$ said they would not change the pricing policy. The respondents also consider that financial support is necessary to cover the costs of implementing the ISPS Code at $70.6 \%$. Finally, no marina has received financial support for the implementation of the ISPS Code.

Possible ways to encourage or strengthen the implementation of the ISPS Code in the marinas, proposed by marinas 'operators are the inclusion of expenditure in the National Strategic Reference Framework (NSRF), and in public or municipal funding.

In conclusion, although security is considered to be a strong quality element for the marinas, the ISPS Code is not implemented by the majority of marinas. Nor do the majority of managers of the Greek marinas consider security as a factor contributing to increasing their competitiveness.

Thanks to the Cross Tabs tool, where a combination of questions is made, other conclusions can be drawn. The data resulting from the cross-checking of two variables in the relationship between security and ownership and the cost of applying ISPS to the marinas. (Siomkos, Vasilikopoulou, 2005). This has shown that no public marina applies the ISPS code, unlike private ones which apply it to only $5.9 \%$. 
The second crossreference relates to questions of ownership and the possibility of supporting the costs of implementing the ISPS Code. This cross showed that private marinas, at $35.3 \%$, can support the costs of applying the ISPS Code, as opposed to public ones, where the figure is only $5.9 \%$.

The third crossreference relates to questions of ownership and the existence of a plan to cover the costs of the ISPS Code. From this analysis we have found that $11.8 \%$ of private marinas have a plan to cover the costs of implementing the ISPS Code, while only $5.9 \%$ of marinas have a plan to cover.

The fourth crossreference relates to questions of ownership and the change in pricing policy, as a result of the implementation of the ISPS Code. From this analysis, it was concluded that $41.2 \%$ of private marinas would not change the pricing policy, while the corresponding share of public tourism was $11.8 \%$.

Finally, the Fifth crossreference deals with questions of the ownership of the system and the need to provide aid to cover the costs of applying the ISPS Code. From the analysis, we note that $47.1 \%$ of private marinas highlight the need to provide financial support for the implementation of the ISPS code. While only $23.5 \%$ of public marinas consider such funding necessary.

\subsection{Marinas which have Applied the ISPS Code}

In Greece the code has been applied at the marinas of Floisvos, Gouvia and Zea. Analyzing Table 2, we observe that Floisvos marina has fewer berths than the Gouvia and Zea, which is down by about $75 \%$ and $45 \%$ respectively. Despite this, its costs in terms of the installation and operating of the ISPS Code were higher than in the other two marinas. In particular, Floisvos spends $28,500 €(25 \%)$ more on the port facility than the Gouvia marina and 52,500€ (46\%) more than the Zea marina. In addition to the cost incurred by the port facility security officers, for the Floisvos marina the cost is $18,500 €$ per year, as opposed to the Gouvia marina, where the corresponding amount does not exceed 4,900€ and $7,000 €$ for the Zea marina.

This difference is due to the fact that Marina Floisvos employs full-time staff in this field and therefore this expenditure is the result of remuneration, unlike Marina Gouvia and Marina Zeas, who for the respective competence employs the marina employees in parallel with their duties and this expenditure is the result of the training required for their certification. Also, the Floisvos marina has a closed surveillance circuit and access system, the facility of which cost $\$ 330,000$, with an annual maintenance cost of $€ 15,000$, unlike the Zeas marina, which cost $1,000 €$, only for the installation of a closed surveillance circuit, and an annual maintenance cost of only $100 €$. On the other hand, the Gouvia marina has not installed such a facility. Also, the Floisvos marina has installed a perimeter lighting and established a cabin in its entrance, projects for which the Floisvos marina has invested $140,000 €$, unlike the other two marinas under study that do not have such facilities. Finally, it is noted that the Floisvos port facility has spent $€ 500,000$ on the fence, unlike the Gouvia marina and Zeas where the cost involved was only $€ 1,350$ and $€ 5,000$ respectively. The small area fencing in the last two marinas made that difference.

Considering the above costs of the Floisvos marina, for example, it is concluded that the Floisvos marina has annual expenditure on the implementation of the Code of $€ 146,000$, and has spent a total of $€ 975,000$ on the installation of the Floisvos marina. On the other hand, the annual costs of Gouvia Marina are estimated at $84,000 €$, with the one-off installation costs for the implementation of the Code reaching 10,750 $€$ and for marina Zeas the annual costs are $60,100 €$ and 18,000 $€$ for the installation costs.

Table2. Greek marinas that have applied the ISPS Code

\begin{tabular}{|l|l|l|l|}
\hline Operations & Floisvos Marina & Gouvia Marina & Zea Marina \\
\hline Berths & 303 & 1235 & 670 \\
\hline Terrestrial zone area & $56,000 \mathrm{~m}^{2}$ & $172,575 \mathrm{~m}^{2}$ & $40,000 \mathrm{~m}^{2}$ \\
\hline $\begin{array}{l}\text { Port facilities security } \\
\text { plan }\end{array}$ & $5,000 €$ & $4,500 €$ & $5,000 €$ \\
\hline $\begin{array}{l}\text { Salaries of Port } \\
\text { facilities Security } \\
\text { officers }\end{array}$ & $18,500 € /$ year & $4,900 €$ & $7,000 €$ \\
\hline Guard cost fencing & $500,000 €$ & $84,000 € /$ year & $60,000 € /$ year \\
\hline $\begin{array}{l}\text { Cost of year } \\
\text { construction }\end{array}$ & $1,350 €$ & 5,000 \\
\hline
\end{tabular}




\begin{tabular}{|c|c|c|c|}
\hline $\begin{array}{l}\text { Installation cost of } \\
\text { closed surveillance } \\
\text { circuit (CCTV) and } \\
\text { access system }\end{array}$ & $330,000 €$ & None & 1,000 only for CCTV \\
\hline $\begin{array}{l}\text { Maintenance cost of } \\
\text { closed surveillance } \\
\text { circuit (CCTV) and } \\
\text { access system }\end{array}$ & $15,000 € /$ year & None & $100 € /$ year only for CCTV \\
\hline $\begin{array}{l}\text { Installation cost of } \\
\text { perimeter lighting }\end{array}$ & $60,000 €$ & None & None \\
\hline $\begin{array}{l}\text { Cabin cost at the } \\
\text { entrance of port facility }\end{array}$ & $80,000 €$ & None & None \\
\hline Main income sources & $\begin{array}{l}\text { Vessels mooring } \\
\text { according to marinas' } \\
\text { pricelist } \\
\text { annual agreements with } \\
\text { high security } \\
\text { requirements customers } \\
\text { estimated annual income } \\
\text { of about: } 500,000 €\end{array}$ & $\begin{array}{l}\text { Vessels mooring } \\
\text { according to marinas' } \\
\text { pricelist } \\
\text { estimated annual income } \\
\text { of about: } 1,500 €\end{array}$ & $\begin{array}{l}\text { Vessels mooring } \\
\text { according to marinas' } \\
\text { pricelist } \\
\text { estimated annual income } \\
\text { of about: } 1,500 €\end{array}$ \\
\hline
\end{tabular}

Source: Spyridon G. (2018), Master Thesis, The economic investigation of the ISPS code implementation at Greece marinas, NTUA

According to the data in the table, Floisvos marina spent a total of $1,121,000 €$ in the first year of operation of the Code, while Gouvia Marina and Zea Marina spent 94,750€ and 78,100€ respectively. The estimated annual revenues for the Floisvos marina amount to $€ 500,000$, while for the Gouvia marina and the Zea marina, it amounts to $1,500 €$, respectively. It follows from the above that the Floisvos marina will have depreciated the installation and implementation of the Code in less than three years, while for the Gouvia and Zea marinas it is not economically viable and therefore they have stopped applying the Code. Although they do not apply the Code because of cost, they provide security services to marina users because they consider security a quality element for the marina. In view of the above, it is concluded that the capacity of a marina is not a determining factor in the amount of the cost of installing and applying the ISPS Code. The expenditure is therefore up to the policy of each marina.

\section{CONCLUSIONS - Proposals}

In the Greek port system, which is an infrastructure of the Yacht sea tourism, there are a considerable number of marinas, shelters and anchors, as well as positions in the country's coastal ports. ISPS code is already applied to sea ports serving international voyages. A rewarding fee for the security of ships and passengers has been introduced by law in these ports.

Marinas are not required to apply the ISPS code, but ships engaged on international voyages and carrying more than 12 passengers are required, and so are the ports or marinas which receive these ships. Although marinas are not obliged to apply the code, there are cases where even a pilot has been carried out. Many measures imposed by the code are also applied in a piecemeal manner to most Greek marinas.

From our investigation after the survey analysis, we conclude that Greek marinas consider security a quality element, which is why they provide various security services such as fencing, cooperation with a security company, entry cards, surveillance system, personal security patrols and registration of incoming and outgoing people and vehicles. According to the questionnaire analysis, the most popular guard measures are the area fencing and the security patrols $(76.5 \%)$, the use of private security firms $(70.5 \%)$, camera surveillance systems $(59 \%)$, the registration of incoming and outgoing people and vehicles $(53 \%)$ and the use of an entry card (35\%).

With regard to the ISPS code, the majority of respondents (78.8\%) have a positive view of the Code as a security tool. With regard to the obligation to apply it, approximately $94 \%$ of the sample indicates that it is not obliged to apply it, and only $5.9 \%$ apply it. The main reasons for not applying the Code are: the non-obligation to implement it (50\%), the high cost of implementation $(25 \%)$, and other reasons (25\%). Despite the non-implemenattion of the Code to the majority of Greek marinas, the 
managers involved in the survey recognize that the implementation of the ISPS Code improves the image of the marina (94.1\%). For the marinas that applied the ISPS Code, $11.8 \%$ observed a decrease in thefts and 5.9\% attracted larger vessels and increased traffic.

In the questions concerning the cost of implementing the code, $58.8 \%$ said that they could not financially support the adoption and implementation of this Code and about $78.8 \%$ of respondents had no plan to cover the costs of its implementation. The respondents also consider that financial support is necessary to cover the costs of implementing the ISPS Code at $70.6 \%$. Finally, no marina has received financial support for the implementation of the ISPS Code. Given the current situation, it is considered that the economic benefit of installing and implementing the ISPS Code is less than the resources available for this implementation. That's why two marinas who had tried to apply the code abandon it.

In view of the above, and particularly because the marinas consider investment in security to be a necessary element in the provision of quality services, we propose first of all the code to be applied in marinas where the heavily-dependent vessels (large yachts) are accepted, in order to attract those ships which are in increasing demand. It must then be universally applicable to all marinas, if necessary. In order to cover the costs, the user requesting greater security is prepared to pay for it, so it can be incorporated into the invoices (costing and priming quality-security). Maybe the contributory fee that has already been imposed on the port funds managed by vessels operating in short sea shipping, should be extended to the marinas.

\section{REFERENCES}

[1] Aschenbruck N. et al. (Eds.), (2012): Future Security 2012, CCIS 318, pp. 522-525.

[2] Colesniuc D. (2013), Cyberspace and Critical Information Infrastructure. Informatica Economica, Vol 17, issue4, pp.123-132.

[3] Crosby P.B. (1979), Quality Is Free. The Art of Making Quality Certain, McGraw Hill, New York.

[4] Feigenbaum A. V. (1993), Creating the quality mindset among senior manager, National Productivity Review.

[5] Fernandez-Sanchez P.A. (2009), International Legal Dimension of Terrorism, Leiden, Martinus Nijhoff. Publishers,p.217

[6] Gilmore J.(1994), The Experience Economy, Harvard Business Review Press, Boston, Massachusetts.

[7] Hellberg P.(2009), Effects of the ISPS CODE on ship and port security- A Swedish perspective, World Maritime University, Sweden.

[8] ILO (2005), Safety and health in ports. ILO code of practice, International Labor Office, Geneva.

[9] ILO-IMO (2004), Security in ports. ILO and IMO code of practice, International Labor Office, Geneva/International Maritime Organization, London.

[10] IMO (2017a). Report of the Maritime Safety Committee on its ninety-eighth session. MSC 98/23. London.

[11] IMO document SOLAS/CONF.5/34 ANNEX I, 12, December 2002. p. 4.

[12] IMO International Convention on the Safety for the safety of life at sea 1974 as amended (SOLAS Convention) (2011), Chapter XI-2, IMO, London.

[13] Juran JM (1988), Quality Control Handbook, 4th Edition, McGraw-Hill, New York.

[14] Karatzias S., (2017), Notes for guidance: Port Security. Water science and technology, NTUA, Athens.

[15] Kotler P., (1994), Marketing Management - analysis, planning, implementation, and control. Eight Edition. Prentice-Hall, New Jersey

[16] Mavromati P., (2013), Port and Port Facility Security, Stamoulis Publications, p.179

[17] Mylonopoulos D., (2004), Shipping. Concepts - Sectors - Structures. Stamoulis publications.

[18] NIST, (2014,) Framework for Improving Critical Infrastructure Cybersecurity. National Institute of Standards and Technology.

[19] Onwuegbuchunam D.,Aponjolosun M., Olatunbosun A.,(2016), Assessment of the Effect of the Implementation of International Ship and Port Facility Security (ISPS) Code on Port Operations (A Case Study of Tin Can Island Port Complex) European Journal of Business and Management Vol.8, No.35.

[20] Pardali A., Giantzi T., (2015), Institutional Legal Modernization in Marine Tourism (Yachting) and Impacts in the Market, Conference Paper, NTUA

[21] Pardali A., Giantzi T. (2018), The Formation of Maritime Tourism (Yachting) Cluster as a Vehicle for Competitiveness Improvement: The Greek Case, International Journal of Research in Tourism and Hospitality, Vol 1, ISSUE 1 PP. 64-74. 
[22] Pardali Aggeliki, (2007), Port Economics and Policy, Stamoulis Publications

[23] Pardali, A., and Miliaraki M. (2006), Marinas as poles for sustainable local tourist development: The case of Greece, Archives of Economic History XVIII: 10-26.

[24] Protonotarios N. (2003), International Code on the Safety of Ships and Port Facilities. Astros Hellas Publications

[25] Ross MacKay (1989), The Welsh economy, University College of North Wales, School of Accounting, Banking and Economics

[26] Siomkos G. and Vasilakopoulou A., (2005), Application Of Analytical Methods on Market Research, Stamoulis Publications

[27] Starr K., Liu J., Casey A., (2000), Regional Impact of Ports, Report 101, Bureau of Transport Economics, Canberra.

[28] Steven Jones, (2006), Maritime security, A practical guide. Threats to maritime trade, The Nautical Institute, UK, pp.2-13.

[29] UNCTAD (2017): Review of Maritime Transport 2017.

Citation: Aggeliki Pardali, et.al. " Implementation of the ISPS Code at Marinas: The Greek Case.". International Journal of Research in Tourism and Hospitality (IJRTH), vol 6, no. 2, 2020, pp. 9-20. doi: http://dx.doi.org/10.20431/2455-0043.0602002.

Copyright: (c) 2020 Authors. This is an open-access article distributed under the terms of the Creative Commons Attribution License, which permits unrestricted use, distribution, and reproduction in any medium, provided the original author and source are credited. 